\title{
Trade Effects of EMU in Long-run: A Country-level Study
}

\section{Payam Hashemi*}

Department of Economics, University of Southern California, USA

\begin{abstract}
This article investigates the impacts of EMU on inter-eurozone trade in a medium- to long-run horizon. The core objective is twofold: first to understand if the inception of EMU has boosted trade among its member states or not, and second to investigate the impact of EMU on each individual member state. To this aim, a balanced panel of 17 OECD countries/unions (euro-12 plus five similar European economies) over 1990-2009 was constructed. Using a gravity type of specification and Pesaran's CCE estimator, it is found that overall EMU has increased inter-eurozone trade by not more than $4.3 \%$. Taking country specific estimates into consideration, I find that the impact of EMU on inter-eurozone trade is non-significant for four of the eurozone economies. This is while Spain and Austria seem to realize double-digit gains in trade as a result of joining the EMU.
\end{abstract}

Keywords: EMU; Currency unions; Bi-lateral trade; Gravity model of trade; Common correlated effect estimator (CCE)

\section{Introduction}

National currencies are believed to have adverse impacts on international trade. In particular, it is argued that transaction costs associated with the exchange of foreign currencies, as well as exchange rate volatility threaten trade among partners.

Pointing to some of these costs, Mundell proposes the theory of optimum currency area. He mentions that, through the unification of their monetary authorities, members of a currency union can boost trade among them and benefit from the new arrangement. However, currency unions come with huge macroeconomic costs, as their members virtually give in their monetary authority. Thus, in practice creation of a currency union depends on how the macroeconomic costs compare with microeconomic benefits.

Until recently there hasn't been any empirical study on trade benefits of a currency union. Rose [1] is the first to statistically analyze the impact of monetary unions on trade. Applying a gravity model to a panel of 186 countries, dependencies, territories, overseas departments, colonies, etc., Rose [1] reaches the conclusion that joining a currency union can further trade amongst members by more than $230 \%$.

Many economists have questioned Rose's results and their external validity. Frankel [2] points to endogeneity of countries' decision to join the currency union as well as Rose's sample of countries, which primarily consists of poor, small or poor and small countries, as potential problems that can make the generalization of Rose's result very questionable, especially to the case of more developed economies.

Creation of the European Economic and Monetary Union (EMU) provided economists with a natural experiment to investigate the effect of currency unions on trade in a sample of developed economies. Early estimates have found considerably small values for the effect of EMU on inter-eurozone trade. Bun et al. [3] show that by 2000, EMU increased trade among its members by no more than 4\%; Faruqee [4] finds that by 2002 EMU boosted trade by about $8 \%$; Micco et al. [5] find the value of $15 \%$ for 1999-2003; and more recently, Frankel [2] finds that eurozone countries have on average experienced a 15\%-boost in bilateral trade after 1999 .

Apart from the overall impact of currency unions, the impact on individual states is also interesting. It seems reasonable to believe that joining a currency union would not increase trade for all individual states to the same degree. Unfortunately, there has been little work in this area and to my knowledge Faruqee [4] is the first to empirically investigate the uneven impact of EMU on trade among member countries. He finds that there is a large difference in trade gains among eurozone states in the first three years after the inception of EMU.

This article focuses on the medium- to long-run impacts of EMU on bilateral trade among member states. Using a recent dataset that covers bilateral trade of 17 OECD economies (euro-12 plus Denmark, Norway, Sweden, Switzerland and the U.K.) from 1990 to 2009, I investigate the overall effect of EMU on inter-eurozone trade as well as its impact on individual member states.

From the econometric point of view, instead of applying the fixed effect (FE) and random effect (RE) estimation methods, which are the most conventional approaches in estimating the coefficients of the gravity model, I use the Common Correlated Effect Mean Group (CCEMG) method, which is originally proposed by Pesaran [6] and furthered by Kapetanios et al. [7]. This technique, as discussed in section 5 offers numerous advantages over its alternatives. First of all, CCE method allows us to deal with the problem of cross-sectional dependence and thus eliminates the huge estimation bias caused by the use of FE and RE methods. The method also allows for factors to be correlated with the regressors and to contain unit roots. Second, CCE does not require an a priori knowledge of unobserved common factors, which makes it a more convenient method compared to other sophisticated methods. Finally, as argued by Kapatanios et al. [7], estimates of CCE method offer good finite sample properties. I believe this study is the first to apply the CCE estimation technique in a gravity model framework.

Thus, the current work contributes to the literature in two ways: on the estimation side, I believe most (if not all) the previous estimates for the trade benefits of EMU are considerably biased, mainly due to the use of inappropriate estimation techniques; from the empirical point

*Corresponding author: Payam Hashemi, Department of Economics, University of Southern California, USA, Tel: +12137402311; E-mail: seyedpayam.hashemi@ usc.edu

Received June 29, 2016; Accepted August 11, 2016; Published August 16, 2016

Citation: Hashemi P (2016) Trade Effects of EMU in Long-run: A Country-level Study. J Glob Econ 4: 208. doi: 10.4172/2375-4389.1000208

Copyright: @ 2016 Hashemi P. This is an open-access article distributed under the terms of the Creative Commons Attribution License, which permits unrestricted use, distribution, and reproduction in any medium, provided the original author and source are credited. 
of view, the use of a panel with larger time dimension not only enables the estimation of trade effect of EMU in a longer horizon, but it also allows for country-specific estimations, which are literally absent in the previous works.

The remainder of this paper is organized as follows. Section 2 reviews the existing literature of currency unions. Section 3 introduces the data used for the purpose of this study. Section 4 presents some stylized facts regarding the trend of bilateral trade among euro-12 economies, as well as the trend for the five European economies that serve as the control group. Section 5 discusses the econometric models and estimation techniques. Section 6 summarizes the results of the econometric analysis. Finally section 7 concludes.

\section{Literature Review}

\section{National currencies and their adverse impact on trade}

The adverse impact of national currencies on international trade has long been noticed in the literature of economics. In particular, it is believed that transaction fees associated with the exchange of foreign currencies as well as exchange rate volatility negatively impact the volume of trade among partners.

Most economists, including Feldstein [8], believe that transaction costs put an extra burden on bilateral trade. Although there's no general rule as to how big the magnitude of this burden is, in the case of Western European economies, transaction fees are estimated to be relatively considerable at about $0.1-0.2 \%$ of their GDP according to Chancellor of the Exchequer [9].

According to Head [10], in today's global economy, the cost of exchange rate volatility is even more burdensome when compared to transaction fees. As mentioned by Engel et al. [11], for a sample of eleven European countries, more than $90 \%$ of the so-called border effect will vanish once they account for foreign exchange volatility.

From the point of view of microeconomic theory, exchange volatility intervenes with the decision of firms on whether to expand their market beyond home or not. Baldwin et al. [12] propose a model that theoretically justifies the trade-deterring effects of exchange rate volatility. Using this model, they show that the volume of trade declines as exchange rate volatility rises. Consequently, it is claimed that a reduction in exchange rate volatility boosts trade among partners through two channels; first by increasing the export of firms who are already engaged in the global market and second by increasing the number of firms which decide to expand their market beyond the local level.

Empirical works on the relationship between exchange volatility and trade result in contradicting conclusions. However, in a thorough survey of the literature, Baldwin et al. [12] argue that if an appropriate methodology is chosen, the empirical results would always confirm the theoretical belief that the exchange volatility has a trade-deterring effect. The magnitude of this adverse impact as discussed by Thursby et al. [13], Dell [14], Rose [1], and Baldwin et al. [12] is quite large, reaching to about $10 \%$ in the long-run.

\section{Currency unions in theory and in practice}

Pointing to some of the barriers caused by national currencies, Mundell proposes the theory of optimum currency areas. In his work, he mentions that trade gains are the main driving force behind the formation of currency unions. One might think that the benefits of an integrated goods market would justify a global currency union, but as
Mundell mentions, unification of the national monetary authorities imposes a cost on its member states, as they would literally give in their macroeconomic authority. This would as Feldstein [8] and Frankel et al. [15] argue increase cyclical instability and unemployment, which are detrimental to national economies in the long run.

In a series of empirical studies, Rose [1], Rose et al. [16], Frankel et al. [17], Glick et al. [18] investigated the trade benefits of joining a currency union. Using a gravity model of bilateral trade for a panel of 186 countries, dependencies, territories, overseas departments, colonies, etc., over six year intervals spanning 1970 to 1995, Rose [1] and Frankel et al. [17] reach the conclusion that joining a currency union can further trade among members by almost $230 \%$. After conducting sensitivity analysis, excluding some countries from the sample and accounting for all possible omitted variables, Rose [1] and Frankel et al. [17] confirm that joining a monetary union would still have a large and significant impact on trade. Rose [1] also acknowledges that since the sample under his investigations deals with currency unions composed of small, poor or small and poor countries, the applicability of his findings to currency unions among more developed and larger economies (such as eurozone states) is rather questionable.

Many economists have criticized Rose [1]. As stated by Frankel [2], apart from the sampling issues, one of the relevant critiques of the socalled "Rose Effect" concerns causality or better stated the endogeneity of the currency union decision. According to Frankel [2] countries choose their currency union partners from those with whom they trade the most, rather than the other way around. In other words much of the correlation observed for currency unions among other countries may be spurious and the existence of such reverse causality can significantly bias the estimations.

The inception of EMU has in essence provided economists with an opportunity to investigate the trade effects of currency unions on a sample of developed economies. Using different econometric techniques, almost all studies have found considerably smaller values for the effect of EMU on inter-eurozone trade, in the short-run. Bun et al. [3] showed that EMU increased trade among its members by only $4 \%$ during the short period of 1999-2000. Micco et al. [3] argued that the volume of trade among the early members of eurozone has increased by at most $26 \%$ in 1999-2003. Faruqee [4] finds the value of about $8 \%$ for 1999-2003. And more recently, Frankel [2] found that Eurozone economies have on average experienced about 15\% increase in bilateral trade after joining the EMU.

\section{Uneven impact of currency unions on member states}

It's not very surprising to see that the members of a currency union are unevenly affected as a result of adopting the single currency.

As it was mentioned in previous sections, one of the channels through which the currency union benefits trade is the elimination of exchange volatility for all member states. Thus, for the start one could expect that within a currency union, members that experienced higher exchange volatility prior to joining the union, would benefit the most from their decision.

Member states are also different in terms of their business demography. While business environment of some member states seem to be more heavily reliant on small enterprises, others might be less dependent on such entities. This would in turn be a source for uneven impact of currency unions on trade. As it is discussed by Baldwin et al. [12], trade-deterring effects of exchange volatility will be amplified with the square of the marginal cost. Since smaller firms are 
deemed to have higher marginal cost, it seems logical to assume that exchange volatility systematically affects smaller firms more severely. Correspondingly, elimination of exchange rate volatility would seem to benefit smaller firms the most. Thus, it seems reasonable to hypothesize that within a currency union, countries whose firm size distribution is more heavily skewed toward smaller firms, ceteris paribus, would benefit the most from joining the union.

In addition to the exchange volatility argument, Faruqee [4] proposes three other sources for the uneven impact of currency unions. He argues that trade openness is an influential factor and helps the member states better absorb the trade benefits of joining a currency union. This way, within a currency union, members that are more open to trade seem to reap the most trade gains from joining the currency union. Faruqee [4] also mentions that countries with more flexibility in shifting their resources to sectors that enjoy comparative advantage realize larger trade gains. Finally, share of intra-industry trade (IIT) seem to play a role. As argued by Faruqee [4], countries that have higher share of IIT prior to adopting the single currency would seem to benefit the most from their decision.

Empirically, the uneven impact of currency unions on member states is less investigated. Faruqee [4] is to my knowledge the first to investigate the issue. Using a panel of 22 industrial countries (which includes all euro-12 economies, except Greece) in 1992-2002, he finds that EMU impacts trade among member states very unevenly. His estimates show that although joining EMU boosts trade by about $8 \%$ overall among eurozone economies, the impact on BelgiumLuxembourg, Finland, France, Ireland and Portugal is statistically insignificant. This is while, as a result of joining EMU, Spain's trade has boosted by $14.0 \%$, the Netherlands' by $13.8 \%$ and Austria's and Italy's by $9.3 \%$ each.

\section{Data Structure}

The primary aim of this research as mentioned in section 1 is to determine the medium- to long-run impacts of EMU on inter-eurozone trade. Hence, the current article mainly focuses on the early members of the union, namely Austria, Belgium-Luxembourg, Finland, France, Germany, Greece, Ireland, Italy, the Netherlands, Portugal and Spain. As it will be discussed later, investigating trade among euro- 12 without using a proper control group would not be very helpful in identifying the real trade effects of EMU. Hence, because of geographical proximity as well as similarity of their economies to the core eurozone countries, I use Denmark, Norway, Sweden, Switzerland and the U.K. as the control group in this study.

Thus, in order to investigate the effect of EMU on inter-eurozone trade, a balanced panel of 16 countries/unions (namely, Austria, Belgium-Luxembourg, Denmark, Finland, France, Germany, Greece, Ireland, Italy, the Netherlands, Norway, Portugal, Spain, Sweden, Switzerland and the U.K.) over the period of 1990-2009 was constructed. Throughout this article, I refer to this sample as OECD17. Given that the panel had an individual dimension $N=240(16 \times 15$ accounting for all possible binary combinations of countries) and the time dimension of $T=20$, the total number of observations mounted to $n \times T=4,800$. This large panel is used for analyzing the overall effects of EMU on inter-eurozone trade.

In order to find the effects of EMU on trade of each member state, the large panel was broken down to 16 sub-panels, each with 300 observations $(n \times T=15 \times 20) .11$ of these sub-panels, corresponding to euro-12 (notice Belgium-Luxembourg is considered as a union), were then used for investigating the medium- to long-run effect of EMU on individual members' trade.

A summary of the data and variables used in this study is presented in Table 1 of the appendix. It is worth mentioning that trade figures for each country-pair over the course of 1990-2009 were extracted from the STAN Bilateral Trade $2010^{1}$ (the data was reported in 2014 USD). GDP figures for each country, also reported in 2014 USD, were obtained from World Bank Statistics division ${ }^{2}$. Other variables such as bilateral distance were extracted from the CHELEM-CEPII database ${ }^{3}$.

\section{Stylized Facts}

From the raw data of trade, two additional variables were constructed. The first is the so-called average annual trade volume (hence forth trade volume) for each country and its trade partners:

$$
T_{i}^{t}:=\sum_{j \neq i} \frac{E X_{i j}^{t}+I M_{i j}^{t}}{2}
$$

Where $E X_{i j}^{t}$ represents the value of exports from country $i$ to country $j$ at time $t$ and $I M_{i j}^{t}$ represents the value of imports from country $j$ to country $i$ at time $t$.

The second variable is constructed from the first with an aim to capture the change in trade since the inception of the EMU. In order to do that, the trade volume of each country was normalized by its corresponding value in 1998 (except for Greece, whose trade volume is normalized by its corresponding value in 2000):

$$
T_{i}^{t / t_{0}}=\frac{T_{i}^{t}}{T_{i}^{t_{0}}}
$$

This new variable, when plotted for each country and its trade partners in 1990-2009, helps visualize the trend of change within and outside of the eurozone, before and after the inception of the EMU.

Figure 1 shows the normalized trade volume for all euro- 12 members and their eurozone trade partners in 1990-2009. As it can be seen from the figure, most euro-12 states realized a small change in volume of trade in the early years of EMU (i.e., between 1999 and 2002). After 2002, the inter-eurozone trade seems to expand tremendously beyond its 1998 level. As the figure suggests, right before the incidence of global financial crisis, euro-12 economies have individually experienced a

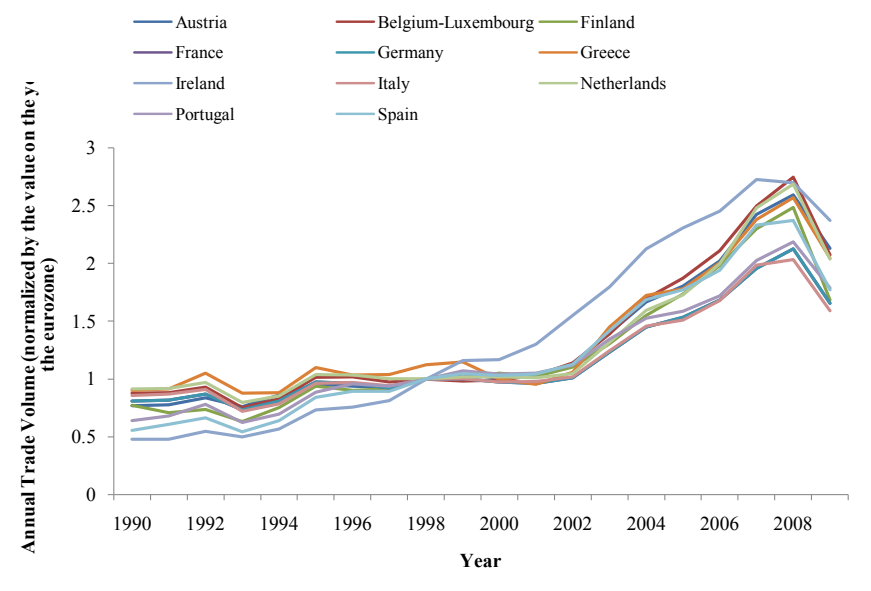

Figure 1: Normalized trade volume for each of the euro-12 economies and its euro-12 trade partners in 1990-2009.

http://stats.oecd.org/Index.aspx?DataSetCode=BTD_ED_2010\#

${ }^{2}$ http://data.worldbank.org/indicator/NY.GDP.MKTP.CD

${ }^{3}$ http://www.cepii.fr/CEPII/en/bdd_modele/presentation.asp?id=8 
trade expansion ranging from $103 \%$ to $174 \%$, when compared to the year prior to joining the EMU.

This, however, is not the whole picture. Apart from the inception of EMU, many other things have happened since 1999 in the global economy that has eventually influenced the global pattern of trade. This is evident in the trend of bilateral trade among the members of our control group. The evolution of normalized trade volume of each of these economies with the other four is shown in Figure 2. As it can be seen from the figure, for this sample of countries just like the euro12 economies, bilateral trade volume has been more or less constant over the course of 1999-2002 and after 2002 the trade volume expanded hugely. Thus, it is obvious that even for those Western European countries that decided not to join the EMU, the bilateral trade has grown by between $25-230 \%$, during 2002 and 2008 .

A similar trend is traceable for the trade between the economies of our control group and their euro- 12 trade partners. Figure 3 shows that trade volumes between our control group and their euro- 12 partners have expanded tremendously since 1998, rising by between $80 \%$ and $195 \%$ in 2008 .

These stylized facts persuade us that apart from the inception of EMU, other variables have played role in the expansion of intereurozone trade since 1999. Thus, any study that is solely based on a panel of eurozone economies would not be able to account for the similarity of changes inside and outside the eurozone and would most

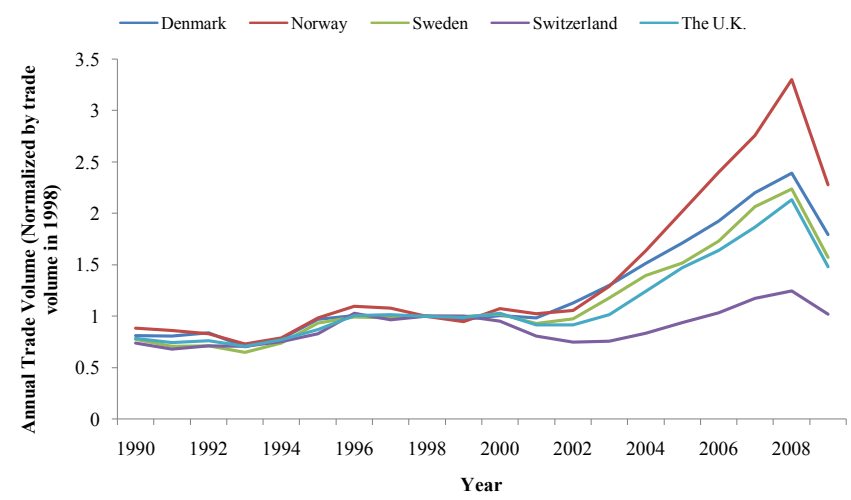

Figure 2: Normalized trade volume for a sample of non-eurozone economies and its non-eurozone trade partners in 1990-2009.

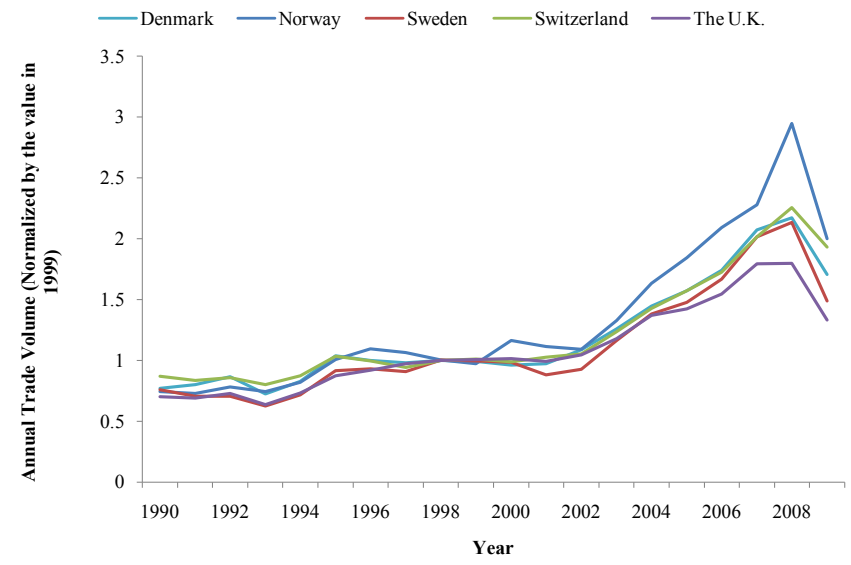

Figure 3: Normalized trade volume between a sample of non-eurozone economies and their euro-12 partners in 1990-2009. probably overestimate the trade effects of EMU. Later in section 6, I discuss how large the size of this bias can be.

\section{Econometric Model and Estimation Techniques}

In this work, in order to study the trade effects of EMU, a version of the gravity model of trade was used. The preliminary econometric model of interest has the form of the equation below:

$$
\begin{aligned}
& \ln X_{i j}^{t}=\beta_{0}+\beta_{1} \ln G D P_{i}^{t}+\beta_{2} \ln G D P_{j}^{t}+\delta_{1} \ln d_{i j}+ \\
& \delta_{2} \text { Lang }_{i j}+\delta_{3} \text { Landlock }_{i j}+\delta_{4} \text { Bord }_{i j}+\delta_{5} E M U_{i j}^{t}+\delta_{6} F C
\end{aligned}
$$

Where $d_{i j}$ is a measure of bilateral physical distance between the countries, while lang $_{i j}$, Landlock $k_{i j}$ and Bord $_{i j}$ are dummies for common language, landlocked countries and countries with shared border. In addition to the common regressors used throughout the literature of trade economics, equation (1) has two additional dummy variables: $E M U_{i j}^{t}$, which acquires the value of 1 if both countries are a part of EMU at time $t$; and the dummy for the global financial crisis $F C$, which is set to 1 if the year is 2009 and 0 otherwise ${ }^{4}$.

The explained variable $X_{i j}^{t}$ is a measure of bilateral trade and is defined as:

$$
\ln X_{i j}^{t}:=\frac{\ln E X_{i j}^{t}+\ln I M_{i j}^{t}}{2}
$$

The trade variable constructed this way, as argued by Baldwin et al. [19], is the most relevant regressand for gravity equations, since it essentially eliminates the possible bias introduced due to the misuse of the logarithm of trade volume.

The most common estimation techniques used by economists in the context of the gravity model are the fixed effect (FE) and random effect (RE) methods. The results of FE and RE estimations of our panel can be found in Table 2 of the appendix. As it can be seen from the table, both methods provide significant estimates with relatively high values of overall $R^{2}$, which is typical of the gravity model estimates. However, these common methods seem to suffer from cross-sectional dependence, as in any other time-series or panel dataset (with large time dimension). This threat seems to be particularly serious in the case of our dataset, given the fact that the countries in our sample are members of a highly integrated region.

To judge on whether the data are cross-sectionally independent or not, one would need to carry out the cross-sectional dependence test. There is a number of ways through which one could investigate the cross-sectional independence. Given that in the case of our panel $\mathrm{N} \gg>\mathrm{T}$, the test under the null hypothesis of cross-sectional independence was carried out through three different frameworks; Pesaran [20], Frees [21] and Friedman [22]. The results of these tests for the overall eurozone are presented in column 1 of Tables 1-3. Following the same logic for the estimation of country specific effects of EMU on euro-12 members, I conducted the cross-sectional dependence tests on our 11 subpanels. The results of these tests can be found in columns 2-12 of the same tables.

As it can be seen from the tables all three methods strongly reject the null hypothesis of cross-sectional independence in our large panel as well as the 11 subpanels. Thus, if used, the estimates of the FE and RE methods most likely result in biased and inconsistent estimators.

As mentioned by Pesaran and Tosetti [23] and Chudik et al. [24], ${ }^{4}$ Construction of this dummy is done based on the belief that in 2009 the European economies have slipped in the recession. According to European Commission Economic and Financial Affair: http://ec.europa.eu/economy finance/explained/ the_financial_and_economic_crisis/why_did_the_crisis_happen/index_en.htm 


\begin{tabular}{|l|c|c|c|c|c|c|c|c|c|c|c|c|}
\hline & Euro-12 & Austria & Belgium & Finland & France & Germany & Greece & Ireland & Italy & Netherland & Portugal & Spain \\
\hline Statistic & 109.242 & 8.537 & 5.790 & 17.448 & 8.776 & 11.375 & 4.536 & 5.058 & 8.723 & 7.998 & 8.235 & 26.109 \\
& $(0.000)$ & $(0.000)$ & $(0.000)$ & $(0.000)$ & $(0.000)$ & $(0.000)$ & $(0.000)$ & $(0.000)$ & $(0.000)$ & $(0.000)$ & $(0.000)$ & $(0.000)$ \\
\hline$\sum_{i \neq j}\left|\rho_{i j}\right|$ & 0.425 & 0.307 & 0.361 & 0.476 & 0.415 & 0.339 & 0.335 & 0.431 & 0.366 & 0.360 & 0.392 & 0.581 \\
\hline Conclusion & & & & & & & & & \\
\end{tabular}

Numbers in the parentheses show the probability of cross-sectional independence;

$\sum_{i \neq j}\left|\rho_{i j}\right|$ is the sum of absolute value of off-diagonal elements.

CSD stands for cross-sectional dependence.

Table 1: The results of Pesaran's test of cross-sectional independence.

\begin{tabular}{|c|c|c|c|c|c|c|c|c|c|c|c|c|}
\hline & Euro-12 & Austria & Belgium & Finland & France & Germany & Greece & Ireland & Italy & Netherland & Portugal & Spain \\
\hline Statistic & 41.602 & 1.193 & 1.579 & 3.103 & 2.665 & 2.066 & 1.304 & 2.493 & 2.018 & 1.519 & 2.088 & 4.725 \\
\hline Conclusion & CSD & CSD & CSD & CSD & CSD & CSD & CSD & CSD & CSD & CSD & CSD & CSD \\
\hline
\end{tabular}

CSD stands for cross-sectional dependence.

Cross-sectional independence hypothesis is rejected at $1 \%$ level, given that $a_{0.01}=0.2468$.

Table 2: Results of Frees' test of cross-sectional independence.

\begin{tabular}{|c|c|c|c|c|c|c|c|c|c|c|c|c|}
\hline & Euro-12 & Austria & Belgium & Finland & France & Germany & Greece & Ireland & Italy & Netherland & Portugal & Spain \\
\hline Statistic & $\begin{array}{c}651.218 \\
(0.000)\end{array}$ & $\begin{array}{l}69.968 \\
(0.000)\end{array}$ & $\begin{array}{l}56.886 \\
(0.000)\end{array}$ & $\begin{array}{c}116.314 \\
(0.000)\end{array}$ & $\begin{array}{l}64.520 \\
(0.000)\end{array}$ & $\begin{array}{l}75.850 \\
(0.000)\end{array}$ & $\begin{array}{l}36.531 \\
(0.000)\end{array}$ & $\begin{array}{l}42.291 \\
(0.000)\end{array}$ & $\begin{array}{l}62.131 \\
(0.000)\end{array}$ & $\begin{array}{l}61.419 \\
(0.000)\end{array}$ & $\begin{array}{l}65.419 \\
(0.000)\end{array}$ & $\begin{array}{l}165.701 \\
(0.000)\end{array}$ \\
\hline Conclusion & CSD & CSD & CSD & CSD & CSD & CSD & CSD & CSD & CSD & CSD & CSD & CSD \\
\hline
\end{tabular}

Numbers in the parentheses show the probability of cross-sectional independence.

Table 3: Results of Friedman's test of cross-sectional independence $\Sigma R M S E$.

there are two main strands in the literature for dealing with error cross-sectional dependence in panels where $\mathrm{N} \gg>\mathrm{T}$, namely the spatial econometric and the residual multifactor approaches.

The spatial econometric approach, as discussed by Chudik et al. [24], assumes that the structure of cross-sectional correlation is related to location and distance among units, defined according to a pre-specified metric given by a connection or spatial matrix that characterizes the pattern of spatial dependence according to prespecified rules. Although helpful in overcoming the problem of crosssectional correlation, this approach has two main drawbacks. First, it requires ex-ante knowledge of the weight matrix, and second it does not allow for slope heterogeneity. The issue of slope heterogeneity is especially important for the purpose of this work, since I anticipate that the EMU has unevenly affected the member states in general, and their trade in particular.

The residual multifactor approach, as explained by Chudik et al. [24], assumes that the cross-sectional dependence can be characterized by a small number of unobserved common factors. Under this framework, the error term is a linear combination of few common time-specific effects with heterogeneous factor loadings plus an individual-specific error term. Estimation of a panel with such a multifactor residual structure can be addressed through the use of statistical techniques such as the maximum likelihood and the Principal Components (PC) methods. Using these techniques, one would be able to overcome the problem of cross-sectional dependence without having an a priori knowledge of the weight matrix. So the multifactor techniques are easier to implement when compared to spatial econometric techniques. However, they would not be able to efficiently account for the slope heterogeneity.

Pesaran [6] has suggested an estimation method, referred to as Common Correlated Effects (CCE), which consists of approximating the linear combinations of the unobserved factors by cross-section averages of the dependent and explanatory variables and then running standard panel regressions augmented with these cross-section averages. CCE and its derivatives have gained tremendous attention over the last couple of years and many empirical economists have used these techniques as alternatives that can account for the shortcomings of FE method.

There are numerous advantages to using Pesaran's CCE method over other sophisticated techniques. First of all, unlike spatial methods, CCE approach does not require an a priori knowledge of unobserved common factors. Second, Pesaran's CCE method allows for slope heterogeneity among units, which makes its application to our panel very favorable. Moreover, as discussed by Kapetanios et al. [7] and Pesaran et al. [23], CCE method yields unbiased and consistent estimates not only in the case of panels with serially correlated errors but also under a variety of other scenarios, including unit roots in the factors and possible contemporaneous dependence of the observed regressors with the unobserved factors. In addition, as shown by Pesaran et al. [23] and Chudik et al. [25], CCE estimators are asymptotically normal under a variety of situations. And finally, Monte Carlo studies by Coakley et al. [26], Kaptanios et al. [7] and Chudik et al. [25] show that CCE estimators are the most efficient and robust among a variety of multifactor models estimates, with Common Correlated Effect Mean Group (CCE-MG) estimators yielding the best results.

Because of its advantages over other conventional techniques, I used Pesaran [6] Common Correlated Effect Mean Group (CCE-MG) method to estimate an unbiased estimator for the EMU dummy. This way, in order to find the overall effect of EMU on inter-eurozone trade, I estimate the coefficients of (2) using the panel with 4800 observations (OECD-17) and CCE estimation technique:

$$
\ln X_{i j}^{t}=\beta_{0}+\beta_{1} \ln G D P_{i}^{t}+\beta_{2} \ln G D P_{j}^{t}+\delta_{1} \text { Euro }_{i j}^{t}+\delta_{2} F C
$$

And in order to find the impact of EMU on each euro-12 member state, I apply the same model and estimation technique to the 11 subpanels, each with 300 observations. 


\section{Results}

\section{Overall effect of EMU on trade}

The result of Pesaran's CCE-MG regression for the overall eurozone is provided in columns 1 and 2 of Tables 4 and 5 .

Table 4 presents the results of regression for the sample that contains only the euro- 12 economies (treatment group), while Table 5 summarizes the result of the same regressions for the sample of OECD17 economies (treatment plus the control group).

At the first glance, it can be seen that all estimates for the overall euro-12 are significant at $1 \%$ level. All estimates indicate that overall, the economic size of the exporting and importing countries have the same effect on trade; in other words, elasticity of trade with respect to importer and exporter countries' income stand at about 0.5 in both specifications and the two samples. The equality of importer and exporter income elasticities indicates that overall for both samples supply and demand forces have approximately the same quantitative influence on trade among partners. Moreover the coefficients of the financial crisis are negative, large and significant, which is aligned with our expectations.

The most relevant coefficient for the purpose of this study is the EMU dummy. All estimates show that overall for euro-12 economies, the coefficient of EMU is positive and significant at $1 \%$ level. Moreover, the estimates of columns 1 and 2 of Table 5 indicate that until 2009, EMU has increased trade by almost $4.3 \%$ among the member states, when compared to the control group ${ }^{5}$. This figure is considerably smaller than Rose's prediction and is much closer to the estimates of Bun et al. [3]. Thus it can be said that adopting EMU has on average increased the trade among its members by $4.3 \%$ over the first 10 years from its inception.

In order to demonstrate our point for using the CCE estimation technique, one can compare the results of CCE estimation with that of FE and RE estimates. As it can be seen from Table 2, of appendix the coefficient of EMU in FE or RE framework would move between 0.158 and 0.168 , corresponding to overall trade gains of about $17.1 \%$ to $18.3 \%$. This is while the estimates in CCE framework suggests that the overall trade gains would barely go beyond $4.3 \%$ level. Thus, with an overestimation of about 13-14 percentage point, one could claim that the magnitude of the FE and RE estimation bias is large and highly misleading.

Notice that I barely referred the reader to the estimates of column 1 and 2 in Table 4. However, there are two reasons for including this table. First, the comparison between the estimates of EMU dummy in Table 4 and Table 5 show that failing to include a control group in this study will lead to an overestimation of the effect of EMU by a considerable amount (from 9.5\% to 4.3\%). This is well aligned with our findings in section 4 . Second, the estimates of EMU in Table 4 can virtually serve as an upper bound for the trade effects of EMU. The coefficient of EMU in equation (2) might vary from one panel to another, depending on the choice of control group. For the purpose of this study, I chose Denmark, Norway, Sweden, Switzerland and the U.K. as the control group. I believe that given the similarities between these 5 economies and the core eurozone states, the difference-indifference estimator would correctly grasp the pure effect of EMU on inter-eurozone states. Other authors might believe that another group of countries would better serve the purpose of the control group. Thus, while my estimates show that the coefficient of the EMU dummy changes in the range of $0.042-0.046$, other authors might find slightly different values, depending on their choice of control group. However, the upper bound estimates of 0.091-0.100 can never be topped, if the same data and methodology is chosen.

Another point is worth mentioning. Previous studies, which mostly focused on the short-run effect of EMU on inter-eurozone trade, found

\begin{tabular}{|c|c|c|c|c|c|c|c|c|c|c|c|c|}
\hline \multirow[b]{2}{*}{ In $G D P_{i t}$} & \multicolumn{2}{|c|}{ Overall Euro-12 } & \multicolumn{2}{|c|}{ Austria } & \multicolumn{2}{|c|}{ Belgium-Luxembourg } & \multicolumn{2}{|c|}{ Finland } & \multicolumn{2}{|c|}{ France } & \multicolumn{2}{|c|}{ Germany } \\
\hline & $\begin{array}{l}0.478^{*} \\
(0.062)\end{array}$ & $\begin{array}{c}0.497^{*} \\
(0.063)\end{array}$ & $\begin{array}{c}0.253 \\
(0.410)\end{array}$ & $\begin{array}{c}0.327 \\
(0.423)\end{array}$ & $\begin{array}{c}0.569 \\
(0.387)\end{array}$ & $\begin{array}{c}0.688^{* * *} \\
(0.405)\end{array}$ & $\begin{array}{l}0.470^{*} \\
(0.113)\end{array}$ & $\begin{array}{l}0.518^{*} \\
(0.109)\end{array}$ & $\begin{array}{l}0.698^{* *} \\
(0.297)\end{array}$ & $\begin{array}{c}0.756^{*} \\
(0.281)\end{array}$ & $\begin{array}{l}-0.213 \\
(0.217)\end{array}$ & $\begin{array}{l}-0.292 \\
(0.266)\end{array}$ \\
\hline In $G D P_{j t}$ & $\begin{array}{l}0.481^{*} \\
(0.062)\end{array}$ & $\begin{array}{l}0.503^{*} \\
(0.063)\end{array}$ & $\begin{array}{l}0.968^{* *} \\
(0.417)\end{array}$ & $\begin{array}{l}0.930^{* *} \\
(0.429)\end{array}$ & $\begin{array}{c}0.511 \\
(0.381)\end{array}$ & $\begin{array}{c}0.436 \\
(0.571)\end{array}$ & $\begin{array}{l}0.527^{*} \\
(0.118)\end{array}$ & $\begin{array}{l}0.574^{*} \\
(0.130)\end{array}$ & $\begin{array}{c}0.221 \\
(0.227)\end{array}$ & $\begin{array}{c}0.214 \\
(0.211)\end{array}$ & $\begin{array}{l}1.212^{*} \\
(0.196)\end{array}$ & $\begin{array}{l}1.331^{*} \\
(0.241)\end{array}$ \\
\hline $\boldsymbol{E M} \boldsymbol{U}_{i j}^{t}$ & $\begin{array}{l}0.046^{*} \\
(0.076)\end{array}$ & $\begin{array}{l}0.042^{*} \\
(0.007)\end{array}$ & $\begin{array}{c}0.120^{*} \\
(0.045)\end{array}$ & $\begin{array}{l}0.112^{* *} \\
(0.044)\end{array}$ & $\begin{array}{l}0.075^{\star *} \\
(0.035)\end{array}$ & $\begin{array}{c}0.067^{* * *} \\
(0.037)\end{array}$ & $\begin{array}{c}0.089^{*} \\
(0.031)\end{array}$ & $\begin{array}{l}0.081^{*} \\
(0.030)\end{array}$ & $\begin{array}{l}0.068^{* *} \\
(0.046)\end{array}$ & $\begin{array}{c}0.062^{\star * *} \\
(0.033)\end{array}$ & $\begin{array}{c}0.022 \\
(0.034)\end{array}$ & $\begin{array}{c}0.013 \\
(0.037)\end{array}$ \\
\hline$F C$ & --- & $\begin{array}{l}-0.153^{*} \\
(0.009)\end{array}$ & --- & $\begin{array}{c}-0.131^{* *} \\
(0.058)\end{array}$ & --- & $\begin{array}{l}-0.159^{*} \\
(0.029)\end{array}$ & --- & $\begin{array}{l}-0.316^{*} \\
(0.048)\end{array}$ & --- & $\begin{array}{l}-0.147^{*} \\
(0.025)\end{array}$ & --- & $\begin{array}{c}-0.159^{*} \\
(0.22)\end{array}$ \\
\hline Constant & $\begin{array}{l}-3.856^{*} \\
(0.564)\end{array}$ & $\begin{array}{l}-4.899^{*} \\
(0.582)\end{array}$ & $\begin{array}{c}-11.615^{*} \\
(2.299)\end{array}$ & $\begin{array}{c}-12.461^{*} \\
(2.446)\end{array}$ & $\begin{array}{l}-6.439^{*} \\
(2.088)\end{array}$ & $\begin{array}{l}-7.501^{*} \\
(2.270)\end{array}$ & $\begin{array}{c}-5.436^{\star *} \\
(2.244)\end{array}$ & $\begin{array}{l}-7.904^{*} \\
(7.904)\end{array}$ & $\begin{array}{c}-2.674 \\
(2.643)\end{array}$ & $\begin{array}{c}-4.078 \\
(2.679)\end{array}$ & $\begin{array}{l}-2.814 \\
(1.842)\end{array}$ & $\begin{array}{c}-3.691^{\star \star \star} \\
(2.016)\end{array}$ \\
\hline \multirow[t]{2}{*}{$\sum R M S E$} & 0.0998 & 0.0909 & 0.1188 & 0.1076 & 0.0860 & 0.0773 & 0.1244 & 0.1012 & 0.0753 & 0.0671 & 0.0776 & 0.0692 \\
\hline & \multicolumn{2}{|c|}{ Greece } & \multicolumn{2}{|c|}{ Ireland } & \multicolumn{2}{|c|}{ Italy } & \multicolumn{2}{|c|}{ The Netherlands } & \multicolumn{2}{|c|}{ Portugal } & \multicolumn{2}{|c|}{ Spain } \\
\hline In $G D P_{i t}$ & $\begin{array}{c}0.590^{\star *} \\
(0.27)\end{array}$ & $\begin{array}{l}0.627^{\star *} \\
(0.252)\end{array}$ & $\begin{array}{c}1.160^{*} \\
(0.113)\end{array}$ & $\begin{array}{l}1.141^{*} \\
(0.10)\end{array}$ & $\begin{array}{l}0.437^{*} \\
(0.156)\end{array}$ & $\begin{array}{c}0.428^{*} \\
(0.142)\end{array}$ & $\begin{array}{c}0.308 \\
(0.253)\end{array}$ & $\begin{array}{c}0.331 \\
(0.263)\end{array}$ & $\begin{array}{c}0.737^{*} \\
(0.210)\end{array}$ & $\begin{array}{c}0.762^{*} \\
(0.190)\end{array}$ & $\begin{array}{l}-0.263 \\
(0.159)\end{array}$ & $\begin{array}{l}-0.166 \\
(0.179)\end{array}$ \\
\hline In $G D P_{j t}$ & $\begin{array}{c}0.356^{* * *} \\
(0.302)\end{array}$ & $\begin{array}{c}0.365 \\
(0.292)\end{array}$ & $\begin{array}{c}-0.453^{*} \\
(0.112)\end{array}$ & $\begin{array}{l}-0.404^{*} \\
(0.138)\end{array}$ & $\begin{array}{l}0.506^{*} \\
(0.099)\end{array}$ & $\begin{array}{c}0.572^{*} \\
(0.094)\end{array}$ & $\begin{array}{c}0.733^{*} \\
(0.214)\end{array}$ & $\begin{array}{l}0.747^{*} \\
(0.224)\end{array}$ & $\begin{array}{c}0.227 \\
(0.244)\end{array}$ & $\begin{array}{c}0.238 \\
(0.222)\end{array}$ & $\begin{array}{c}1.374^{*} \\
(0.163)\end{array}$ & $\begin{array}{c}1.344^{*} \\
(0.189)\end{array}$ \\
\hline$E M U_{i j}^{t}$ & $\begin{array}{c}0.036 \\
(0.036)\end{array}$ & $\begin{array}{c}0.026 \\
(0.034)\end{array}$ & $\begin{array}{c}0.021 \\
(0.037)\end{array}$ & $\begin{array}{c}0.026 \\
(0.039)\end{array}$ & $\begin{array}{l}0.110^{* *} \\
(0.047)\end{array}$ & $\begin{array}{l}0.101^{* *} \\
(0.046)\end{array}$ & $\begin{array}{c}0.025 \\
(0.031)\end{array}$ & $\begin{array}{c}0.019 \\
(0.032)\end{array}$ & $\begin{array}{c}0.061 \\
(0.044)\end{array}$ & $\begin{array}{c}0.062 \\
(0.042)\end{array}$ & $\begin{array}{l}0.288^{*} \\
(0.057)\end{array}$ & $\begin{array}{l}0.269^{*} \\
(0.056)\end{array}$ \\
\hline$F C^{t}$ & --- & $\begin{array}{l}-0.151^{*} \\
(0.047)\end{array}$ & -- & $\begin{array}{l}-0.069 \\
(0.048)\end{array}$ & -- & $\begin{array}{c}-0.201^{*} \\
(0.027)\end{array}$ & -- & $\begin{array}{l}-0.115^{\star} \\
(0.025)\end{array}$ & --- & $\begin{array}{c}-0.102^{*} \\
(0.033)\end{array}$ & -- & $\begin{array}{l}-0.270^{*} \\
(0.044)\end{array}$ \\
\hline Constant & $\begin{array}{c}-4.90^{\star *} \\
(2.04)\end{array}$ & $\begin{array}{l}-6.11^{*} \\
(2.27)\end{array}$ & $\begin{array}{c}3.33 \\
(2.69)\end{array}$ & $\begin{array}{c}2.56 \\
(2.71)\end{array}$ & $\begin{array}{l}-3.03 \\
(2.28)\end{array}$ & $\begin{array}{c}-4.57^{\star \star} \\
(2.19)\end{array}$ & $\begin{array}{c}-5.52^{\star *} \\
(2.28)\end{array}$ & $\begin{array}{l}-6.48^{*} \\
(2.48)\end{array}$ & $\begin{array}{l}-4.20 \\
(4.06)\end{array}$ & $\begin{array}{l}-5.15 \\
(3.87)\end{array}$ & $\begin{array}{l}-7.57^{*} \\
(1.34)\end{array}$ & $\begin{array}{l}-9.34^{*} \\
(1.39)\end{array}$ \\
\hline$\sum R M S E$ & 0.1052 & 0.0969 & 0.0951 & 0.0899 & 0.0814 & 0.0692 & 0.0812 & 0.0764 & 0.1070 & 0.1033 & 0.1161 & 0.0997 \\
\hline
\end{tabular}

The numbers in the parentheses correspond to the standard error of each variable;

Estimators are significant at $1 \%$ level if they're signified by *; $5 \%$ level if they're signified by **; and $10 \%$ level if they're signified by ***. 
small effects of EMU on trade, but they have mostly remained rather optimistic about the long-run effects of the union. In contrast to their overall effect of EMU on trade has remained rather small. This can be due to the fact that EMU was adopted after decades of economic and political integrations among European economies (especially euro12). It is, however, possible that EMU has had larger trade gains for newer eurozone members, the economies of which were not so deeply integrated before joining the EMU. More time will be needed to evaluate this possible effect.

\section{Uneven effect of EMU across state members}

Column 3 through 24 of Tables 4 and 5 present the result of country-specific estimates. Table 4 summarizes the result of estimation using the euro-12 sample and just like before, the values of EMU dummies found in this table are not very informative and merely serve as an upper bound for the effect of EMU for each member state. However, the estimates of Table 5 belong to our OECD-17 sample and are the most relevant for the purpose of our discussion.

As it can be seen from Table 6, the effect of EMU on trade among member countries has been very uneven. Four of the member states, namely Germany, Greece, Ireland and the Netherlands, have not realized any effect as a result of joining the eurozone. For the remaining countries, however, the effect of euro in increasing the inter-eurozone trade has been relatively large. Particularly for the case of Austria and Spain, the increase in trade as a result of joining the EMU has been at about $12.7 \%$ and $21.2 \%$, respectively. The quantitative effect of EMU on each member state's trade is summarized in Table 6.

There is no single explanation for why euro-12 economies are affected so differently as a result of adopting the single currency and investigating into this issue is in need of a more comprehensive dataset beliefs, my estimates show that even in the medium- to long-run, the that can shed light on different aspects and features of each member

countries trade portfolios.

Members of euro-12 are very different in terms of their economic structure, business environment, degree of integration prior to joining the currency union, trade composition, etc. All these factors can contribute to the non-uniform effect of EMU on trade. Table 7 highlights some key differences of euro- 12 economies that might have contributed to the uneven trade effects of EMU.

The first and foremost source of difference among euro-12 economies is their level of exchange volatility prior to joining the EMU. As it was discussed in the literature review, those eurozone members who experienced higher exchange volatility prior to joining the EMU would probably benefit the most from their decision to join the union. In this study in order to show exchange volatility differential among members, I used historical exchange rates of $\mathrm{OANDA}^{6}$ and calculated the exchange rate volatility as the difference between min and max exchange rate (in 1990-1999) normalized by the average value of exchange rate in the same period. The result of the calculations (column 1 of Table 7) shows that prior to joining the EMU, member states experienced different levels of exchange volatility. As it can be seen from the table, exchange volatility for Finland, Italy, Spain and Greece is way above the average for euro-12 economies. This is in agreement with the observation that these countries (excluding Greece) outperformed the overall euro-12 in terms of trade.

The second source of difference in euro-12 economies deals with their business demography. In the literature review I discussed that the effect of exchange volatility is amplified with the share of small size enterprise. Thus, one can expect to see members with large share of small enterprise in their business demography, ceteris paribus, reap the most gain from joining the EMU. Unfortunately, there doesn't seem to be a comprehensive database on business demography of euro12 economies that goes back in time to 1990s. However, using the Structural Business Statistics (SBS) of Eurostat in 2010-2012 ${ }^{7}$, I was able to estimate the share of micro and small businesses for each of euro-12

\begin{tabular}{|c|c|c|c|c|c|c|c|c|c|c|c|c|}
\hline \multirow[b]{2}{*}{ In $G D P_{i t}$} & \multicolumn{2}{|c|}{ Overall Euro-12 } & \multicolumn{2}{|c|}{ Austria } & \multicolumn{2}{|c|}{ Belgium-Luxembourg } & \multicolumn{2}{|c|}{ Finland } & \multicolumn{2}{|c|}{ France } & \multicolumn{2}{|c|}{ Germany } \\
\hline & $\begin{array}{l}0.478^{*} \\
(0.062)\end{array}$ & $\begin{array}{l}0.497^{\star} \\
(0.063)\end{array}$ & $\begin{array}{c}0.253 \\
(0.410)\end{array}$ & $\begin{array}{c}0.327 \\
(0.423)\end{array}$ & $\begin{array}{c}0.569 \\
(0.387)\end{array}$ & $\begin{array}{c}0.688^{\star \star \star} \\
(0.405)\end{array}$ & $\begin{array}{l}0.470^{*} \\
(0.113)\end{array}$ & $\begin{array}{l}0.518^{\star} \\
(0.109)\end{array}$ & $\begin{array}{l}0.698^{\star *} \\
(0.297)\end{array}$ & $\begin{array}{l}0.756^{*} \\
(0.281)\end{array}$ & $\begin{array}{l}-0.213 \\
(0.217)\end{array}$ & $\begin{array}{l}-0.292 \\
(0.266)\end{array}$ \\
\hline In $G D P_{j t}$ & $\begin{array}{l}0.481^{*} \\
(0.062)\end{array}$ & $\begin{array}{l}0.503^{*} \\
(0.063)\end{array}$ & $\begin{array}{l}0.968^{* *} \\
(0.417)\end{array}$ & $\begin{array}{l}0.930^{* *} \\
(0.429)\end{array}$ & $\begin{array}{c}0.511 \\
(0.381)\end{array}$ & $\begin{array}{c}0.436 \\
(0.571)\end{array}$ & $\begin{array}{l}0.527^{\star} \\
(0.118)\end{array}$ & $\begin{array}{l}0.574^{*} \\
(0.130)\end{array}$ & $\begin{array}{c}0.221 \\
(0.227)\end{array}$ & $\begin{array}{c}0.214 \\
(0.211)\end{array}$ & $\begin{array}{l}1.212^{*} \\
(0.196)\end{array}$ & $\begin{array}{l}1.331^{*} \\
(0.241)\end{array}$ \\
\hline$E M U_{i j}^{t}$ & $\begin{array}{l}0.046^{*} \\
(0.076)\end{array}$ & $\begin{array}{l}0.042^{*} \\
(0.007)\end{array}$ & $\begin{array}{l}0.120^{*} \\
(0.045)\end{array}$ & $\begin{array}{l}0.112^{* *} \\
(0.044)\end{array}$ & $\begin{array}{l}0.075^{\star *} \\
(0.035)\end{array}$ & $\begin{array}{c}0.067^{\star \star *} \\
(0.037)\end{array}$ & $\begin{array}{l}0.089^{*} \\
(0.031)\end{array}$ & $\begin{array}{l}0.081^{*} \\
(0.030)\end{array}$ & $\begin{array}{l}0.068^{* *} \\
(0.046)\end{array}$ & $\begin{array}{c}0.062^{* * *} \\
(0.033)\end{array}$ & $\begin{array}{c}0.022 \\
(0.034)\end{array}$ & $\begin{array}{c}0.013 \\
(0.037)\end{array}$ \\
\hline$F C$ & --- & $\begin{array}{l}-0.153^{*} \\
(0.009)\end{array}$ & --- & $\begin{array}{c}-0.131^{* *} \\
(0.058)\end{array}$ & --- & $\begin{array}{l}-0.159^{*} \\
(0.029)\end{array}$ & --- & $\begin{array}{l}-0.316^{*} \\
(0.048)\end{array}$ & --- & $\begin{array}{c}-0.147^{*} \\
(0.025)\end{array}$ & --- & $\begin{array}{c}-0.159^{*} \\
(0.22)\end{array}$ \\
\hline Constant & $\begin{array}{l}-3.856^{*} \\
(0.564)\end{array}$ & $\begin{array}{l}-4.899^{*} \\
(0.582)\end{array}$ & $\begin{array}{c}-11.615^{\star} \\
(2.299)\end{array}$ & $\begin{array}{c}-12.461^{*} \\
(2.446)\end{array}$ & $\begin{array}{l}-6.439^{*} \\
(2.088)\end{array}$ & $\begin{array}{l}-7.501^{*} \\
(2.270)\end{array}$ & $\begin{array}{c}-5.436^{\star \star} \\
(2.244)\end{array}$ & $\begin{array}{l}-7.904^{*} \\
(7.904)\end{array}$ & $\begin{array}{l}-2.674 \\
(2.643)\end{array}$ & $\begin{array}{l}-4.078 \\
(2.679)\end{array}$ & $\begin{array}{c}-2.814 \\
(1.842)\end{array}$ & $\begin{array}{c}-3.691^{\star \star \star} \\
(2.016)\end{array}$ \\
\hline \multirow[t]{2}{*}{$\sum R M S E$} & 0.0998 & 0.0909 & 0.1188 & 0.1076 & 0.0860 & 0.0773 & 0.1244 & 0.1012 & 0.0753 & 0.0671 & 0.0776 & 0.0692 \\
\hline & \multicolumn{2}{|c|}{ Greece } & \multicolumn{2}{|c|}{ Ireland } & \multicolumn{2}{|c|}{ Italy } & \multicolumn{2}{|c|}{ The Netherlands } & \multicolumn{2}{|c|}{ Portugal } & \multicolumn{2}{|c|}{ Spain } \\
\hline In $G D P_{i t}$ & $\begin{array}{c}0.391 \\
(0.265)\end{array}$ & $\begin{array}{c}0.444^{\star \star \star} \\
(0.259)\end{array}$ & $\begin{array}{l}1.111^{*} \\
(0.101)\end{array}$ & $\begin{array}{c}1.109^{*} \\
(0.101)\end{array}$ & $\begin{array}{l}0.308^{* \star} \\
(0.156)\end{array}$ & $\begin{array}{l}0.349^{*} \\
(0.100)\end{array}$ & $\begin{array}{l}0.458^{\star *} \\
(0.201)\end{array}$ & $\begin{array}{l}0.486^{\star *} \\
(0.205)\end{array}$ & $\begin{array}{c}0.323 \\
(0.216)\end{array}$ & $\begin{array}{c}0.356^{\star \star *} \\
(0.209)\end{array}$ & $\begin{array}{l}-0.074 \\
(0.176)\end{array}$ & $\begin{array}{c}0.040 \\
(0.188)\end{array}$ \\
\hline In $G D P_{i t}$ & $\begin{array}{c}0.512^{* * *} \\
(0.274)\end{array}$ & $\begin{array}{c}0.491^{* * *} \\
(0.265)\end{array}$ & $\begin{array}{c}-0.424^{*} \\
(0.116)\end{array}$ & $\begin{array}{l}-0.409^{*} \\
(0.124)\end{array}$ & $\begin{array}{l}0.626^{*} \\
(0.105)\end{array}$ & $\begin{array}{l}0.632^{*} \\
(0.074)\end{array}$ & $\begin{array}{l}0.562^{*} \\
(0.204)\end{array}$ & $\begin{array}{c}0.566^{*} \\
(0.206)\end{array}$ & $\begin{array}{l}0.498^{\star *} \\
(0.208)\end{array}$ & $\begin{array}{l}0.500^{* *} \\
(0.028)\end{array}$ & $\begin{array}{c}1.23^{*} \\
(0.183)\end{array}$ & $\begin{array}{l}1.172^{\star} \\
(0.200)\end{array}$ \\
\hline$E M U_{i j}^{t}$ & $\begin{array}{l}0.024 \\
(0.24)\end{array}$ & $\begin{array}{c}0.018 \\
(0.023)\end{array}$ & $\begin{array}{c}0.014 \\
(0.024)\end{array}$ & $\begin{array}{c}0.017 \\
(0.026)\end{array}$ & $\begin{array}{l}0.073^{* *} \\
(0.034)\end{array}$ & $\begin{array}{l}0.068^{* *} \\
(0.033)\end{array}$ & $\begin{array}{c}0.016 \\
(0.020)\end{array}$ & $\begin{array}{c}0.013 \\
(0.021)\end{array}$ & $\begin{array}{c}0.048 \\
(0.029)\end{array}$ & 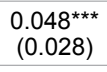 & $\begin{array}{l}0.192^{*} \\
(0.052)\end{array}$ & $\begin{array}{c}0.179^{*} \\
(0.050)\end{array}$ \\
\hline $\mathrm{FC}^{\mathrm{t}}$ & --- & $\begin{array}{l}-0.137^{*} \\
(0.038)\end{array}$ & --- & $\begin{array}{c}-0.078^{\star *} \\
(0.037)\end{array}$ & --- & $\begin{array}{l}-0.160^{*} \\
(0.031)\end{array}$ & --- & $\begin{array}{l}-0.112^{*} \\
(0.027)\end{array}$ & --- & $\begin{array}{c}-0.101^{*} \\
(0.026)\end{array}$ & --- & $\begin{array}{c}-0.260^{*} \\
(0.038)\end{array}$ \\
\hline Constant & $\begin{array}{c}-4.012^{\star *} \\
(1.605)\end{array}$ & $\begin{array}{l}-4.811^{*} \\
(1.772)\end{array}$ & $\begin{array}{c}3.772^{\star \star \star} \\
(2.029)\end{array}$ & $\begin{array}{l}3.475^{*} \\
(2.110)\end{array}$ & $\begin{array}{c}-2.801^{*} \\
(1.752)\end{array}$ & $\begin{array}{l}-4.124 \\
(1.729)\end{array}$ & $\begin{array}{c}-5.014^{*} \\
(1.900)\end{array}$ & $\begin{array}{l}-5.860^{*} \\
(1.968)\end{array}$ & $\begin{array}{l}-1.123 \\
(2.974)\end{array}$ & $\begin{array}{l}-2.015 \\
(2.882)\end{array}$ & $\begin{array}{l}-9.198^{*} \\
(1.289)\end{array}$ & $\begin{array}{c}-10.646^{*} \\
(1.291)\end{array}$ \\
\hline$\sum R M S E$ & 0.1066 & 0.0995 & 0.1067 & 0.1019 & 0.0782 & 0.0679 & 0.0890 & 0.0839 & 0.1010 & 0.0974 & 0.1220 & 0.1072 \\
\hline
\end{tabular}

The numbers in the parentheses correspond to the standard error of each variable;

Estimators are significant at $1 \%$ level if they're signified by *; $5 \%$ level if they're signified by **; and $10 \%$ level if they're signified by ***.

Table 5: CCE estimates of (2) on the OECD-17 sample.

${ }^{6} \mathrm{http}: / / w w w . o a n d a . c o m / c u r r e n c y / h i s t o r i c a l-r a t e s /$

${ }^{7}$ http://ec.europa.eu/eurostat/web/structural-business-statistics/data/main-tables 


\begin{tabular}{|c|c|c|c|c|c|c|c|c|c|c|c|c|}
\hline & Eurozone & Austria & Belgium & Finland & France & Germany & Greece & Ireland & Italy & Netherland & Portugal & Spain \\
\hline $\begin{array}{l}\text { Increase in } \\
\text { Trade (\%) }\end{array}$ & 4.7 & 12.7 & 7.8 & 9.3 & 7.0 & $\begin{array}{c}\text { Non- } \\
\text { significant }\end{array}$ & $\begin{array}{c}\text { Non- } \\
\text { significant }\end{array}$ & $\begin{array}{c}\text { Non- } \\
\text { significant }\end{array}$ & 7.6 & Non-significant & 4.9 & 21.2 \\
\hline
\end{tabular}

Table 6: Quantitative effect of EMU on each member state's trade with its eurozone partners.

\begin{tabular}{|l|c|c|c|}
\hline Country & $\begin{array}{c}\text { Exchange Rate } \\
\text { Volatility }\end{array}$ & $\begin{array}{c}\text { Share of Small } \\
\text { Businesses }\end{array}$ & $\begin{array}{c}\text { Share of Intra- } \\
\text { Industry Trade }\end{array}$ \\
\hline Austria & $29 \%$ & $98.1 \%$ & $75 \%$ \\
\hline Belgium & $30 \%$ & $99.0 \%$ & $81 \%$ \\
\hline Finland & $53 \%$ & $98.6 \%$ & $50 \%$ \\
\hline France & $25 \%$ & $99.0 \%$ & $87 \%$ \\
\hline Germany & $29 \%$ & $97.0 \%$ & $80 \%$ \\
\hline Greece & $74 \%$ & $99.6 \%$ & Not Available \\
\hline Ireland & $29 \%$ & $98.0 \%$ & $53 \%$ \\
\hline Italy & $43 \%$ & $98.1 \%$ & $60 \%$ \\
\hline $\begin{array}{l}\text { The } \\
\text { Netherlands }\end{array}$ & $30 \%$ & $98.7 \%$ & $61 \%$ \\
\hline Portugal & $40 \%$ & $99.3 \%$ & $55 \%$ \\
\hline Spain & $54 \%$ & $99.2 \%$ & $72 \%$ \\
\hline Average & $\mathbf{4 0} \%$ & $\mathbf{9 8 . 6} \%$ & $\mathbf{6 7} \%$ \\
\hline
\end{tabular}

country has experienced the highest exchange volatility among all euro-12 economies prior to joining the EMU. It also has the highest share of small-size enterprises. These two could potentially guarantee high gains from joining the union. But why isn't it the case for Greece?

First of all, Greece's exchange volatility prior to joining the EMU is a result of continuous devaluation of drachma against the major European currencies, like German mark, French franc, Italian lira, Spanish peseta, etc. Historical data of OANDA shows that on the decade prior to joining the EMU, drachma depreciated by $45-60 \%$ against each of these currencies. This continuous devaluation enabled the Greek economy to maintain its competitive advantage in Europe. However, adopting euro in 2001 has totally eliminated the room for devaluation and virtually stole the country's main source of competitive advantage. Second, access to funding is a rather challenging aspect of small businesses across euro-12. This problem as mentioned by Vetter [27] is most significant in the case of Greece, which gives the Greek small enterprises a meager chance of survival. These two reasons can justify why Greece has not been able to benefit from joining the currency union.

A number of arguments can justify the ineffectiveness of EMU in boosting the trade for Germany. German economy has some specific features that distinguish it from other euro-12 economies. First of all, Germany's export is heavily skewed toward the manufacturing goods and a huge share of German export goes to the countries outside the eurozone, particularly to the U.S., the U.K., China and Switzerland. In other words, Germany because of its export composition has remained very much integrated with and heavily reliant on its non-eurozone trade partners. On the other hand, imports to Germany hasn't grown after the inception of the EMU, mainly because the German government has implemented policies, which in effect prevent salary increases and secures low unemployment rates within the borders of Germany. This implies that the German demand for imports has virtually stayed steady since the inception of EMU. These two facts can explain why the EMU has been ineffective in boosting the German trade.

Of course, each of these hypotheses needs further justifications through the use of data and econometric models. However, since the primary aim of this article was not to investigate into the roots of the uneven effect of the currency union on member states, I only proposed possible explanations, without actually validating them.

\section{Conclusion}

This paper investigated the impact of EMU on member states' trade condition in a medium- to long-run horizon. In order to do so I used a panel of 17 OECD economies (euro-12 plus Denmark, Norway, Sweden, Switzerland and the U.K.) over 1990-2009 and used Pesaran's CCE-MG estimation technique.

I accomplished the task in two separate steps. In the first step I studied the overall effect of EMU on trade among euro-12 economies over the course of 1999-2009. The results of CCE-MG regression analysis indicate that until 2009, EMU has had a small yet statistically significant impact on trade among its member countries. More specifically I found that euro-12 economies on average have experienced an increase of about $4.3 \%$ as a result of joining the currency union. I showed that 
using CCE-MG estimates reduced the bias associated with estimates of $\mathrm{FE}$ and RE methods by almost 13 to 14 percentage points.

Previous studies, which mostly focused on the short-run effect of EMU on inter-eurozone trade, also found small effects of EMU on trade, but they have mostly remained optimistic about the long-run effects. In contrast to their beliefs, I showed that even in the mediumto long-run, the overall effect of EMU on trade has remained rather small. This can be due to the fact that EMU was adopted after decades of economic and political integrations among European economies (especially euro-12). It is, however, possible that the EMU has had larger trade benefit for newer eurozone members, the economies of which were not so deeply integrated before joining the euro. More time will be needed to evaluate this possible effect.

In the second step, I studied the effect of EMU on each individual member state. Given the differences in the structure of core eurozone economies, it is not very surprising to see that they are unevenly influenced by their decision to join the currency union. The results of the analysis indicated that EMU has been ineffective in boosting the inter-eurozone trade for four of the member countries (i.e., Germany, Greece, Ireland, and the Netherlands). Considering the remaining eight countries, Spain, with $21.2 \%$ increase in trade, seems to have benefited the most from joining the currency union, while Austria seems to be in the second place with $12.7 \%$ increase in trade. Finland with $9.7 \%$, Belgium-Luxembourg with $7.8 \%$, Italy with $7.6 \%$, France with $7.0 \%$ and Portugal with $4.8 \%$ are in the next places.

Given their differences, it is not very surprising to see that euro-12 economies are unevenly influenced by their decision to join the currency union. However, to see insignificant gains for four of the member states is somehow surprising. One can offer a number of explanations for this particular observation. I suspect that the main reason for the Netherlands and Ireland not realizing any trade gains from joining the EMU is the fact that they both have had small exchange volatility and small share of intra-industry trade prior to joining the EMU. The combination of these two could potentially eliminate the trade gains of joining the monetary union. For the case of Greece, it can be said that for most of the decade prior to joining the eurozone, the country had been able to maintain its competitive advantage through currency devaluation. Adopting euro as its official currency has eliminated Greece's competitive advantage and thus it wouldn't be very surprising to see the trade of Greece unaffected as a result of joining EMU. Finally in the case of Germany, a combination of domestic economic policies which has virtually kept the private consumption constant, together with the specific export structure, didn't allow for the country's trade expansion with its euro-12 partners.

\section{References}

1. Rose AK (2000) One Money, One Market: Estimating the Effect of Common Currency on Trade. Economic Policy 15: 7-46.

2. Frankel JA (2008) The Estimated Effects of Euro on Trade: Why Are They Below Historical Effects of Monetary Unions Among Smaller Countries? National Bureau of Economic Research.

3. Bun M, Franc K (2002) Has the Euro Increased Trade? Tinbergen Institute Discussion Paper.

4. Faruqee $\mathrm{H}$ (2004) Measuring the Trade Effects of EMU. IMF Working Paper.

5. Micco A, Stein E, Ordonez G (2002) Should the UK Join EMU?

6. Pesaran MH (2006) Estimation and Inference in Large Heterogeneous Panels with a Multifactor Error Structure. Econometrica 74: 967-1012.

7. Kapetanios G, Pesaran MH, Yagamata T (2011) Panels with Non-Stationary Multifactor Error Structures. Journal of Econometrics 160: 326-348.
8. Feldstein M (1997) The Political Economy of European Economic and Monetary Union: Political Sources of and Economic Liability. Journal of Economic Perspectives 11: 23-42.

9. Chancellor of the Exchequer (2003) Statement by the Chancellor of the Exchequer on UK Membership of the Single Currency.

10. Head K (2007) Elements of Multinational Strategy.

11. Engel C, Rogers JH (2004) European Product Market Integration after Euro. Economic Policy 19: 348-384.

12. Baldwin RE, Skudelni F, Taglioni D (2005) Trade Effects of the Euro: Evidence from Sectoral Data. ECB Working Papers.

13. Thursby JG, Thursby MC (1987) Bilateral Trade Flows, the Linder Hypothesis and Exchange Risk. The Review of Economics and Statistics 69: 488-495

14. Dell Ariccia MG (1998) Exchange Rate Fluctuations and Trade Flows: Evidence from the European Union. IMF Working Papers.

15. Frankel JA, Rose AK (1997) Is EMU more Justifiable Ex Post than Ex Ante. European Economic Review 41: 753-760.

16. Rose AK, van Wincoop E (2001) National Money as a Barrier to Internationa Trade: The Real Case for Currency Union. American Economic Review 91 : 386-390.

17. Frankel JA, Rose AK (2001) An Estimate of the Effect of Common Currencies on Trade and Income. Quarterly Journal of Economics 117: 437-466.

18. Glick R, Rose AK (2002) Does a Currency Union Affect Trade? The Timeseries Evidence. European Economic Review 46: 1125-1151.

19. Baldwin RE, Taglioni D (2006) Gravity for Dummies and Dummies for Gravity Equations. National Bureau of Economic Research.

20. Pesaran MH (2004) General diagnostic tests for cross section dependence in panels.

21. Frees EW (1995) Assessing Cross-Sectional Correlation in Panel Data. Journal of Econometrics 69: 393-414

22. Friedman M (1937) The Use of Ranks to Avoid the Assumption of Normality Implicit in the Analysis of Variance. Journal of the American Statistical Association 32: 675-701.

23. Pesaran MH, Tosetti E (2011) Large Panels with Common Factors and Spatial Correlation. Journal of Econometrics 161: 182-202.

24. Chudik A, Pesaran MH (2013) Large Panel Data Models with Cross-sectional Dependence: A Survey. The Oxford Handbook of Panel Data.

25. Chudik A, Pesaran MH, Tosetti E (2011) Weak and strong cross section dependence and estimation of large panels. The Econometrics Journal 14: 45-90.

26. Coakley J, Fuertes A, Smith R (2006) Unobserved Heterogeneity in Panel Time Series Models. Computational Statistics and Data Analysis 50: 2361-2380.

27. Vetter S (2014) Business Demographics and Dynamics in Europe. Deutsche Bank Research Briefing on European Integration. 